\title{
"Just because I can". To the Mars and Back: A Study of the Rebirth of Science Fiction in Andy Weir's The Martian
}

\author{
Ahmed Abdelsattar Abdelaziz Keshk \\ English Department, Faculty of Education, Ain Shams \\ University, Roxy, Cairo, Egypt.
}

\section{ABSTRACT:}

Science fiction works have usually been misjudged as works that do not fit to either scientific studies or fictious literary works. The most optimistic views have considered the genre mere imaginary works that tell farfetched scientific stories that might happen one day after thousands of years. This literary genre has been revolutionised at the hands of many famous novelists and critics, for example, H.G.Wells, Isaac Asimov and many others. These changes were mainly concerned with introducing technological advances and possible scientific achievements to attract different readers. Andy Weir's The Martian as the researcher tries to prove, has revolutionised the whole science fiction genre. In this novel, Weir over crossed traditional boundaries of science fiction genre to include the traditions of the robinsonades and the detective stories. Even the way Weir presents science is different from the heritage of science fiction works. Science and technology in The Martian has nothing to do with aliens and weird advanced technology, it rather depends on already known scientific theories and usual forms of technology. The real difference and the main focal point is mainly on the Martian himself, Mark Watney, who managed to survive alone on Mars for over 500 sols by using his knowledge of science. Even on the narrative side, Weir 
To the Mars and Back: A Study of the Rebirth of Science Fiction in Andy Weir's The Martian

manages to combine between the rigid fixed form of diaries and the interesting sense of humour that overcomes any feeling of disappointment. This allowed Weir to invite his readers to go along an interesting journey to Mars and back without any remorse or feeling of boredom. Through the use of the thematic approach, the researcher explores the journey of Mark Watney to study and to analyse the form and theme of The Martian.

Key words:

Science Fiction, The Martian, Andy Weir, Mark Watney, Sol, Mars. 


\section{"Just because I can"(The Martian,294). To the Mars and Back: A Study of the Rebirth of Science Fiction in Andy Weir's The Martian}

"Science fiction is the literature of might be" (C.J. Cherryh)

Ahmed Abdelsattar Abdelaziz Keshk

English Department, Faculty of Education, Ain Shams University, Roxy, Cairo, Egypt.

Science fiction is a real large subject to be discussed thoroughly in a single critical research paper. Any reader seeking deeper understanding is advised to go back to John Clute and Peter Nicholls detailed Encyclopaedia of Science Fiction. The present study is not a complete account of the genre, but rather an attempt to trace a line of a specific mode of literature, that is now called science fiction, to the present day. The text examined is Andy Weir's The Martian (2014) which as the paper will explain later - has renovated the whole genre again content and form wise.

The obvious place to begin a critical research paper of science fiction is with an accurate definition of the genre. Even though it may sound as easy task; yet defining this literary genre is often the subject of a heated debate. Even for many of its proponents, science fiction seems difficult to define with precision. For some critics, it consists of fiction concerned only with future expectations; for others it is a prophecy in a literary form than anything else; for yet others it is a fiction that mainly focuses on space adventures. Actually, however, the term "science fiction" embraces a wide range from the almost realistic to the extreme fancy. This very nature of science fiction has motivated many critics and novelists to suggest new names to the genre than 
"science fiction". For example, Robert Heinlein's solution to the breadth of science fiction is to call the whole field "speculative fiction" - fiction about things that did not yet happen - and he limited the name science fiction to a more scientifically accurate subclass (368-369). Westfahl also agrees with Heinlein and adds other possible subclasses like undisguised fantasy (The $\mathrm{Oz}$ Books), pseudo scientific fantasy (Bradbury's Martian Stories), sociological speculation (H.G. Well's World Set Free), and adventure stories with exotic and non-existent locale (Flash Gordon) (192-193). Within the same content, Heinlein defines science fiction as:

Speculative fictions in which the author takes as his first postulate the real world as we know it, including all established facts and natural laws. The result can be extremely fantastic in content, but it is not fantasy; it is legitimate - and often very tightly reasoned - speculation about the possibilities of the real world. (369)

Unfortunately, Heinlein's definition is not clear because he does not provide an accurate account of some of the used terms in his definition such as fantastic and fantasy. Furthermore, his definition suggests that science fiction is based on reality with some imaginary elements. This makes it a fancy not a fantasy as the definition points. Fantasy and fantastic in a literary sense mean that all elements are outside the existing known order whereas fancy and fanciful mean that some of these elements belong to reality. The definition of science fiction is getting more ambiguous when applying

\section{ELLS Vol.8 No.I (40) December 2017}


it on the characters, events and settings. While some of the characters in science fiction are best described as realistic, the settings and the events are more fanciful. This indicates a clear overlapping between the terms fancy and fantasy as well as the need for another more accurate term to define science fiction.

Darko Suvin has provided a helpful definition of the term science fiction by clarifying that, "science fiction is a literary genre whose necessary and sufficient conditions are the presence and interaction of estrangement and cognition, and whose main formal device is an imaginative framework alternative to the author's empirical environment" (7-8). He further adds that estrangement differentiates science fiction from any other realistic literary genre whereas cognition separates it away from myth, folktale and fantasy (8). In this sense, Suvin implicitly positions science fiction between estrangement and cognition. The movement from cognition to estrangement is achieved via what he calls 'the novum' (plural: nova), that is the fictional device that highlights the difference between the world the reader lives in and the world of the science fiction text. This novum is not a specifically fixed thing; it can be a material thing, for example a spaceship or a time machine, or a conceptual thing such as a new hybrid species or gender. By this 'cognitive estrangement', Suvin believes that science fiction helps to provide a new perspective in understanding the world as readers know it.

In his book The Science of Science Fiction Writing, James Gunn defines science fiction as "the literature of change... [it] deals with the effects of change on people in the real world as it can be projected into the past, the future, or to distant places. It often concerns itself with scientific or technological change, and it usually involves matters whose importance is greater than the individual or the community;

\section{$\begin{array}{lllll}E L L S & V o l & \text { No.I } & \text { (41) December } 2017\end{array}$}


often civilization or the race itself is in danger" (102-113). Gunn further develops his idea about the definition of science fiction in his book The Road to Science Fiction in part by what it is not rather than what it is. He notes that science fiction does not contain fixed activities or locales nor does it seek to reach traditional solutions to traditional problems. He further points out the difficulty of finding a single definition of science fiction upon which readers and critics can agree upon as "the most important, and most divisive, issue in science fiction is definition". (2000, 73).

Reading and studying the previous as well as many other definitions of science fiction, the researcher believes that science fiction is a fiction that prepares its readers to accept future life changes by showing them as normal and necessary. This does not mean that science fiction is a prophecy rather than reflecting readers' passion for drastic science and technological innovations and consequent societal impacts.

Actually, science fiction has no business playing the role of a prophet. It aims at entertaining its readers rather than predicting the ways scientific development will reach. Following this idea, T. O'Conor Sloane defines science fiction as "fiction, founded on, or embodying always some touch of natural science (103). As mentioned, this definition includes only fiction and science, with no mention of prophecy or prediction or any stimulating idea for scientists engaging in any serious effort to suggest predictions of the future.

Science fiction is not also a form of fantasy, for the appeal of science fiction is not the same as the appeal of fantasy. Science fiction is concerned more with ideas of reality, not of make-believe. It focuses more on physical and scientific explanations, not with supernatural and magical 


\section{Dr. Ahmed Abdelsattar Abdelaziz Keshk}

powers. It is a literary genre of ideas rather than imagination. No matter how farfetched some ideas of science fiction might look like, they are always within the boundaries of possibility.

It is worth noting that science fiction is a literature with a heritage that goes back to ancient times. The seeds of science fiction were planted thousands of years ago where humans started dreaming of the great possibilities of the future. Thus, there is no way of setting the birth date of science fiction; yet many critics incline to mark the second century with a Greek named Lucian who satirized his own society with a device of an imaginary moon voyage as the real beginning of the genre. Although many literary forms contained certain features of science fiction since then; yet the beginning of the Industrial Revolution in the Eighteenth century empowered science and the idea of mankind challenging the impossible barriers became valid.

As the Industrial Revolution burst upon the Victorian world, writers began to write fantastic tales based upon the great scientific discoveries and the consequent fast rhythm of change. This idea was highly adopted by the beginning of the nineteenth century with the great scientific miracles the world witnessed. Suddenly, there seemed to be a very real possibility that tomorrow might bring a better world with no boundaries where the verb (can) prevails and the skies are no longer a limit. All of that helped to the widespread of science fiction as the form of literature that reflects the spirit of this era. Marshall B. Tymn elaborates this idea in his article "A Brief History and Review of Criticism" by saying

The Nineteenth century was

fascinated with ideas of science and progress, and its mood was generally one of optimism. The machine age had been

\section{ELLS Vol.8 No.I (43) December 2017}


"Just because I can"

To the Mars and Back: A Study of the Rebirth of Science Fiction in Andy Weir's The Martian

inaugurated, and its impact on

fiction was tremendous. Popular magazine, such as Century, Cosmopolitan, Harper's, Atlantic Monthly and Saturday Evening Post kept the public interest keen with stories featuring new mechanical devices and scientific marvels. (42)

Writing stories about the new scientific discoveries and the unlimited future possibilities is an experience that almost every major writer in America and in Europe went through back then. One of the most prominent names is the scientist, journalist and teacher Herbert George Wells (15561946) with his landmark The Time Machine. Not only was the novel introducing a bold brand new idea of travelling through time, more importantly, the novel was considered a social commentary. Throughout this novel, Wells succeeded in criticizing the exploitation of the working classes as well as attacking the prejudiced English class system. With Wells, science fiction began to take a form and direction, turning into a medium of ideas than a set of adventures.

During the Twentieth century, science fiction has developed in new directions and has come to have a clear distinguished identity of its own. Thanks to John Campbell who introduced the famous science fiction magazine Astounding (known later as Analog) and moved up science fiction a huge step further. Writers of this era were still motivated to write about machinery and scientific advancement. Astounding and other similar science fiction magazines helped the literary genre to have certain defining features. Readers of such magazines expected certain characteristics of each story they are going to read. Action-

\section{ELLS Vol.8 No.I}

(44)

December 2017 
oriented, sexless, and simple language are the common features of science fiction back at the 1930s. However, drastic changes began taking place after World War II. Many critics refer these changes to the dropping of the nuclear bomb and the consequent changes in the scientific consciousness. Regardless how deep the world war affected science fiction, it cannot be compared with the effect of the launching of the first Sputnik in 1957 that put an end to the old conventions of science fiction. The launch of the first artificial Earth Satellite (Sputnik) has put an end to the dominance of science fiction writers as the only source for stories about space adventures. This led science fiction writers to search for new topics and ideas related to our daily lives. Science fiction has become more and more concerned with "ideas and with such un-alien entities as social forces, it is turning away from little green men with unpronounceable names to considerations of the question what if ....?" (Kafka, 47).

Late Twentieth century science fiction has also witnessed another shift of interest concerning ideas and style. During the 1980s and the 1990s there was an unmistakable bias towards (a) characters with whom readers can identify and sympathize. That is characters with whom readers can identify and like; (b) a story that does not break the known orders of chronology and narration; and (c) a clear and easy prose style that does not aim to reflect scientific issues as complex ones. By and large, the science fiction novel of that time is no longer attempting to break the common conventions of the novel. A famous example of these features is Pynchon's Gravity's Rainbow that discusses the moral balance of officer Tyrone Slothrop between choosing to either use a rocket that will allow the Americans to walk on the moon; even though being programmed and designed by the Nazi research institute, or not to . 
Two apparently contradictory features of science fiction written in the late twentieth century are the following. The first is that over this time, more and more science fiction novels appeared every year including many undeniable masterpieces to the extent that science fiction grew into one of the most prominent branches of publishing. The second is that during this period the novel has no longer become the most appealing form of science fiction. As visual science fiction (such as cinema and TV) dominated whereas prose science fiction has declined. Professional science fiction artists became increasingly prevalent as the century progressed. The dominance of visual media in science fiction over written books has sustained till the early decades of the twentieth first century when Andy Weir introduced The Martian to the world of readers. In spite of being rebuffed by literary agents when trying to get prior books published. Andy Weir decided to put the book online in a serial format of one chapter followed by another. Weir then decided to make a version of the book available on Amazon at 99 cents (the minimum he could set the price) (The Martian, White, 2). The book rose to the top of Amazon's list of the best selling science fiction books, where it sold 35,000 copies in three months. This in turn drew the attention of publishers: Podium Publishing an audio publisher and later on Crown in 2013 to start a new era of the history of science fiction.

In her article "The Man who Rediscovered Mars", Sara Vilkomerson reflects the phenomenal success of The Martian by noting, "The Martian debuted on the New York Times best seller list at No.12 this past March. Since then, the book (now in paperback) has sold 18,000 copies and Ridley Scott is directing the adaptation" (34). The fantastic adaptation of the book to the screen has won the heart of many critics. According to the Academy of Motion Picture 
Arts and Sciences, The Martian, for the first time for a science fiction movie, has been nominated for the 2016 Oscar Best Picture.

Showing great personal interest in exploring Mars and space travelling, Andy Weir the software programmer grew up reading Heinlein Clarke, Asimov and many other fantasy authors. One of these books was Heinlein's Red Planet that affected Weir so deep and only since he loved the idea of Mars exploration. Now Andy Weir's story about exploring the red planet has become a bestseller and even more a Hollywood blockbuster directed by Ridley Scott and starring Matt Demon. It made \$ 54 million on its opening weekend and has raked in a worldwide box office topping \$ 435 million and still going strong (Weissmueller, 38).

The Martian opens with the question 'what if an astronaut had to survive on Mars?'. The promise of Weir's book is that a crew of US astronauts land on Mars. But just after six days of landing on Mars, Mark Watney and his crew members face a massive sandstorm that forces them to evacuate at once. As the crew race to their escape vehicle, Watney is hit by a flying antenna to place him where his colleagues can't find. Thought to be dead and not even found, the crew decides to leave Mars at once to save their lives. On another far side of Mars, Watney was surviving the impact and stitching up his wounds.

What follows is more like an episode of a reality TV show of survival, but shot in the outer space. As a biologist and an engineer, Watney first turns his focus on providing water and food. Cleverly and relying on existing scientific theories, Watney grows potatoes on the floor of his domeshaped habitat. The real challenge that Watney has to face and to succeed in or else die is to provide enough food and water for the coming four years, the time of the next man mission to Mars. Readers are invited to share with Watney

\section{ELLS Vol.8 No.I (47) December 2017}


every moment of both success and failure in his journey to solve this life threatening equation.

Being a resourceful scientist, Watney started with driving a rover out to find the Pathfinder, NASA's ancient Mars explorer (launched in 1996) and hacks into its computer to contact Earth. He also chemically turns his urine into drinking water, and when something breaks, he simply fixes it with duct tape. Moreover, he recycles his own waste to fertilize potatoes, burns rocket fuel to create water and generally manages to create enough sustenance to theoretically satisfy his needs till the next expected mission. Everything seemed to go on his side until an inevitable disaster (Martian frost and chemical explosions) put an end to his plans. Eventually after much NASA delays and negotiations, a round-trip mission is engineered by Watney's crewmates.

Since day one till the day he was rescued, Watney jokes to himself in homemade videos and sadly notes that his only source of entertainment is the old disco hits and tapes left behind by his crew. Regardless the fact that he might die alone at any moment or may be left alone to die, Watney for the most part is ironic, funny with smart notes. He further takes pride in the fact that, on this planet, whatever he does or wherever he goes, he is the first human being ever to do that. This black sense of humor adds a new dimension to the character of Watney. Readers will go from nail biting to roll on the floor laughing and back again in a reading experience of excitement and enjoyment. This sharp, funny and thrilling, with just the right amount of scientific facts allowed Weir to attract the technical details along with enough keen wit to satisfy hard science fiction fan and general readers alike. This, in turn, helped Weir to "draw the 
audience in, inviting it to solve each problem along with Watney"(Semley, 59).

Some readers and critics may believe that Weir's idea of surviving on the red planet is farfetched and described as unbelievable; yet science fiction "unlike other literatures, assumes that change is the natural order of things"(Colatrella, 16). This is a bold statement considering other realist narratives promoting social change. This motivated many critics and novelists to distinguish between more realistic and less realistic forms of science fiction. According to many readers, the kind of science fiction that is most highly valued by the literary and academic establishments is that of the more realistic nature. Adopting this idea, Gary Westfahl highly ranks science fiction works that are related and connected with reality by noting

The most effective fiction in the genre is that which touches on reality in as many places as possible... The reader must be able to draw the lines of extrapolation from his own experience or environment - the world in which he lives today - through the intervening linkages of logic, emerging at the new place to which the writer has taken him (208).

Westfahl only focuses on science and the idea that the writer of science fiction works should avoid scientific errors and accurately investigate the credibility of the ideas and the information presented in the literary work. This does not mean at all that any science fiction writer is asked to do a postgraduate work in physics, mathematics and chemistry before writing. Writer of science fiction should be safe from 
scientific criticism as long as they avoid gross errors in their novels.

Though Weir is no exception to the previous unspoken code of science fiction writing, The Martian is a meticulously researched work in every aspect. From the geology, chemistry, and botany aspects to the number of daily calories that Watney needs in order to stay alive on Mars. These are all evidences of the extended researches and studies that Weir adopted before starting to write. Even more, Weir earned praise from NASA engineers for his efforts. In an interview with Andy Weir, he was asked how he gathered his accurate scientific knowledge about space travelling and synthesizing it into something that makes sense even though he is just a computer programmer. Weir replied:

I started off by being a lifelong space nerd -- I love space travel, spaceships. My whole life I've had this as a hobby, and I watch a lot of nonfiction books about space, and so I started out with more than a layman's knowledge of this stuff. But mostly it was just tons and tons of research (Weissmueller, 41).

In Weir's futuristic novel of science innovation and survival, the protagonist, Mark Watney addresses readers with unique ideas to solve his untraditional problems on Mars. These solutions are mainly based on accurate and contemporary scientific theories. Scientists of chemistry, botany, physics and experts of space travelling alike share their admiration for the accuracy and the innovation of the ideas presented in The Martian. Weir remarks that, "the other thing that was cool was that I had 3, 000 fact checkers. 
There's nothing a nerd loves more than telling you you're wrong on math, and I can confirm this because I myself am a nerd, and so I would get emails saying, "You got this wrong, you got that wrong". Some screw-ups made it through to the final copy, but not many" (41).

Being more or less realistic is not the only classification of science fiction works. The most famous classification of science fiction works is hard and soft science fiction. Hard science fiction is characterized by highlighting and focusing on the accurate detail in the natural sciences, especially physics, astrophysics and chemistry or even on accurately portraying possible worlds of more advanced technology. In the light of this idea, Andy Weir's The Martian belongs to hard science fiction. On the other hand, soft science fiction focuses on social sciences such as psychology, economics, political science, sociology and anthropology. The term can be used also to describe "absurd" science and cardboard characters.

The previous categories of science fiction and other categories share certain features that distinguish science fiction from any other literary genre. The first feature is completeness. Completeness means that science fiction works must be based on scientific principles and modern technology without neglecting its social role. Weir's The Martian is mainly based on the most advanced theories of science as well as depending on the state of the art forms of technology yet it highlights a very important social issue, namely refusing racial discrimination. Throughout the journey of saving the American astronaut Mark Watney, different races and nations played vital roles. Indian, Chinese, Russian, Asian and European scientists and institutions helped NASA in its rescue mission. Without their help, Watney would have been still stranded on Mars. Every attempt to rescue him led by only one of these was a 
complete failure, until they reached an agreement and put their differences aside.

The second feature of science fiction works is conviction. Due to its name, science fiction works discuss innovative suggestions and present future forms of life. Thus, science fiction does not only predict possible forms of future but it also creates living examples of these forms. If the reader is not convinced of what is presented in the work, it will be almost impossible for the work to be accepted. This requires the writers of science fiction works to discuss and convince the reader with the possibility and the credibility of the presented innovative ideas. In The Martian, Mark Watney convinces his readers with the logic behind and before making any decision. Mainly this conviction is based on scientific logic. To Weir, readers are not only convinced by the futuristic vision he creates but they also participate and share a great part of it. Moreover, readers predict the consequences of every decision made by Watney in his survival mission on Mars, feel his disappointment if he fails and share his happy moments once he succeeds because of Watney's style in convincing his readers with the decision he takes. In log entry: Sol 94, Watney shares his thoughts with his reader and starts to convince them with the following plan by saying:

Home sweet home! Today I write from my gigantic, cavernous Hab! The first thing I did when I got in was wave my arms wildly while running in circles. Felt great! I was in that damn rover for twenty-two sols and could not even walk without suiting up. I'll need to endure twice that to get to Ares 4, 
but that's a problem for later. After a few celebratory laps around the $\mathrm{Hab}$, it was time to get to work. First, I fired up the oxygenator and atmospheric regulator. Checking the air levels, everything looked good. There was still $\mathrm{CO} 2$, so the plants hadn't suffocated without me exhaling for them. Naturally I did an exhaustive check on my crops, and they're all healthy... (107-108).

The third feature of science fiction is communicating with fans of science fiction works differ from communication of any other literary genre. Simply, science fiction fans appreciate many scientific details and use their imagination to test the validity of possible future scientific theories. This in turn requires the writers of these stories to communicate their ideas with their readers in a way that both satisfies their curiosity and answers all of their questions. This idea is reflected in many log entries of Mark Watney. Some of these entries were addressing the curious minds and answering many questions that might come across the minds of science fiction readers. For example, Log Entry: Sol 41 where Watney survives an explosion. Everything looks good, yet for a science fiction reader many questions need answers, so Watbney does communicate with his readers by noting:

I spent the day running full diagnostics on every system in the Hab. It was incredibly boring, but my survival depends on these machines, so it had to be done. I can't just assume an explosion did no long-term 
damage. I did the most critical tests first. Number one was the integrity of the Hab canvas. I felt pretty confident it was in good shape...Then I checked the oxygenator. If that stops working and I can't fix it, I'm a dead man. No problems. Then the atmosphere regulator. Again, no problem. Heating unit, primary battery array, $\mathrm{O} 2$, and N2 storage tanks, water reclaimer, all three airlocks, lighting systems, main computer...on and on I went (45).

The fourth feature of science fiction works is being didactic. This didactic side of science fiction is reflected in many aspects, first the protagonists of science fiction are always collective, never individual persons (although individuals might appear as exemplary or representative figures). In The Martian, Mark Watney is the prominent figure; yet he is not the only protagonist of the novel, add to him Commander Lewis, Venkat Kapor, Annie Montrose, Teddy Sanders, Cathy Warner and the lists of names go on. The Martian does not record the diaries of a stranded astronaut on Mars, rather it records the efforts of a multinational team of every culture to save a single human soul. The real protagonist is not only the brave Mark Watney, but the creative and innovative team that believed in the possibility of saving Watney regardless of the countless obstacles they faced. Andy Weir concludes The Martian with this note of collective protagonists, "The cost for my

\section{ELLS Vol.8 No.I}

(54)

December 2017 


\section{Dr. Ahmed Abdelsattar Abdelaziz Keshk}

survival must have been hundreds of millions of dollars. All to save one dorky botanist. Why bother? ... They did it because every human being has a basic instinct to help each other out. It might not seem that way sometimes, but it's true... If a train crashes, people will line up to give blood. If an earthquake levels a cit, people all over the world will send emergency supplies.... And because of that, I had billions of people on my side" (368-369)

The didactic feature of science fiction works is also reflected in another aspect, namely the emphasis on the phenomena of "the idea as a hero". A close reading of The Martian shows that Andy Weir has neglected the idea of narrating how his astronaut feels, whom he misses or even his personal future plans. On the contrary, the core of the events is scientifically discussing the challenging possibility of any human to survive for a long time on the red planet depending on the existing scientific theories. This helps readers in focusing on questioning the scientific logic of this hypothesis instead of being distracted with any other personal details. Some of Watney's logs sound like an interesting scientific lesson for any reader who might face a similar problem. Watney focuses on the phenomena he faces and the problem he tries to solve. Then he starts with the possible hypotheses for solving the problem. Then he approaches it with a detailed study of the possible risks. Some of his ideas fail terribly, but instead of describing his disappointment, Weir focuses only on the studied phenomena and explains to his readers what went wrong. An interesting example of this idea is how Watney introduces the problem of water shortage to the readers and then the possible solutions. Explaining why some of these solutions went wrong and finally illustrating how he succeeded. Starting from Log Entry: Sol 40, Watney lives his failure and celebrates his success with his

\section{ELLS Vol.8 No.I (55) December 2017}


experiments to produce water while scientifically explaining every single detail to his readers.

So I ran into a bunch of problems

with my water plan. My idea is to make 600 liters of water. That means I'll need 300 liters of liquid O2. I can create the $\mathrm{O} 2$ easily enough. It takes twenty four hours for the MAV fuel plant to fill its 10liter tank with $\mathrm{CO} 2$. The oxygenator can turn it into $\mathrm{O} 2$, then the atmospheric regulator will see the $\mathrm{O} 2$ content in the $\mathrm{Hab}$ is high, and pull it out of the air, storing it in the main $\mathrm{O} 2$ tanks....Then I'll release hydrazine, very slowly, over the iridium catalyst, to turn it into $\mathrm{N} 2$ and H2. I'll direct the hydrogen to a small area and burn it...Next, I sacrifice a space suit to the cause. I needed an air hose... I cut a hole in the top of the plastic and duct-taped the hose in place...The hydrogen will be hot after the reaction, and it will want to go up in the chimney, then burn it as it comes out.. Then I had to invent fire... They say no plan survives first contact with implementation. Here's what happened... (28-41)

The last feature of science fiction works is the religious tone. According to Joanna Russ, science fiction is not only "didactic, but very often dwed, worshipful and 
religious in tone" (113). Some critics even go to the extent that the sense of wonder that readers feel while reading science fiction works indicates a religious background. The history of science fiction clearly witnessed many examples of religious works such as Arthur C. Clarke's Nine Billion Names of God and Olaf Stapledon's Last and First Men. Joanna's remark might be sound, but contemporary science fiction is greatly variegated and any critical statement of the type "science fiction is such and such" will be negated by the counter examples that can be introduced by anybody even slightly acquainted with the genre. Many writers have produced great science fiction works which has little or nothing to do with religion and Andy Weir's The Martian is no exception. Although Weir, himself, did not frankly discuss this idea in the novel or at any interview; yet many readers and critics believe that The Martian has a religious undertone. This idea is crystallized in Watney's attempt to produce water. He uses the wood of the Cross to start a fire that ended up successfuly with fifty liters of water that saved his life for a certain time. After all, it is the cross and its wood specifically that saved his life.

Martinez is a devout Catholic. I knew that. What I didn't know was he brought along a small wooden cross... I chipped his sacred religious item into long splinters using a pair of pliers and a screwdriver... There were plenty of wires and batteries around to make a spark. But you can't just ignite wood with a small electric spark. So I collected ribbons of bark from local palm trees... Point is, the process worked! (33) 
Furthermore, some readers believe that the story of The Martian highlights the importance of having faith in what you believe in, and in many times all you have to do is to trust your instincts, and God will lead you through hard times and this is exactly what Watney unexpectedly did in many instances.

In the light of the previous featurs, science fiction correspondingly has three functions: the narrative can provide "entertainment", the scientific information can furnish a scientific "education", and the accounts of new inventions can offer "inspiration" to inventors who might actually build the proposed inventions or something similar to it. Consequently, there are three types of audiences for science fiction: the general public, seeking to be entertained; younger readers seeking science education and working scientists searching for new innovative ideas. As explained previously, The Martian covers these three functions and addresses the different types of audience skillfully.

It is worth noting that one of the most prominenet imaginative features of science fiction is "to roll back the heavens for an inhumanly expanded horizons" (West, 281). Space travel is a dominant theme in the world of science fiction since the ancient times. Narratives of travel and adventure were among the most popular modes of ancient culture. There is a few ancient stories of space travel. In Scipio's Dream, Cicero tells a dream in which Scipo travels from Earth to heaven via a number of celestial spheres. This voyage is used as a literary device for criticising and reconsidering Earthly events. Similarly in 165 A.D. Lucian of Samosata wrote A True Story which describes extraterrestrial life and wars between planets of the moon and Venus.

\section{ELLS Vol. 8 No.I}

(58)

December 2017 
Adventures within the solar system are also common in modern and contemporary science fiction. Broadly speaking, these adventures can be classified into two main branches, first 'travels through time' as corollary of 'travels through space'. The most famous and prominant example of this branch is H.G.Wells' The Time Machine. Second branch is travelling to other celestial planets never rehabiliated before. In recent years, speculation about Mars has been fueled by information gained from NASA exploratory ventures such as the 1997 Pathfinder Rover, the 2003 Mars Exploration Rovers, and the 2007 Phoenix Mars Lander, as well as celebrated works of fiction such as Kim Stanley Robinson's Mars Trilogy (1992-96), Greg Bear's Moving Mars (1993) and Geoffrey Landis' Mars Grossing (2000). Actually, Mars does not lack for attention, but what the above works suggest is that readers of science fiction works about Mars need ways of making sense of the information presented.

Although The Martian is praised for its scientific accuracy; yet a deeper reading of the novel reveals few inaccurate scientific information. First of these is the dust storm. Many experts notify that the dust storm that sets everything in motion at the beginning of the novel is not accurate. Although Mars does indeed get dust storms; yet the pressure of the atmosphere is so thin that the speed of the wind is almost negligible. Weir himself does admit that the sand storm is used to "force the astronauts off the planet, so I allowed myself some leeway" (Zack,42).

Second is the gravity of Mars. Throughout Watney's adventure on Mars, Weir portrayed his main character walking, working and moving on the surface of the Red Planet in the same way he does on Earth. Whereas in reality, the Red Planet has about $30 \%$ of the gravity of Earth. Weir deliberately neglected this scientific fact anout Mars because 
if he had not done so, Watney's tasks would have been almost impossible. Modifying the rover throughout many long sols, reshaping the pathfinder and rebuilding the trailer in order to survive would be almost impossible tasks if both of Watney's feet are not firmly touching the ground.

Regardless of these fictious sides of Mars presented in The Martian, Weir succeeds in presenting many accurate scientific facts to his readers. First, the Martian soil. After becoming stranded on the surface of the Red Planet, Watney resorts to using a combination of his own waste, water and Martian soil to grow a small crop of potatoes in order to survive. Actually the Martian soil is not sterile and it is possible to grow plants and as Dave Lavery, programme exceutive for solar system exploration at NASA, "we actually have experiments going on right now using simulated Mars soil, and it indicates that's a very realistic idea"(Zack,41).

The second scientific fact is the orbital dynamic. Perhabs one of the best factual aspects of the novel is the accuracy of the travel time spent to and from Eath and Mars. Till now, manned space missions have ventured no further than the moon. Using the current propulsion technology, The Martian reveals the bitter truth of space flight. It would take two years and half for around trip mission to Mars. Unlike other science fiction works where the characters whizz from one point at the outerspace to another, the author has done real computations to present scientifically accurate information and calculations to his readers.

Another scientifically accurate fact about Mars presented in the novel is the tornadoes. In the novel, readers are surprised to read about giant tornadoes that are so strong to seemingly tear up from the surface into the sky. If the Martian atmosphere is so thin, can it really form such

\section{ELLS Vol.8 No.I}

(60)

December 2017 


\section{Dr. Ahmed Abdelsattar Abdelaziz Keshk}

tornadoes? The answer is yes. Mars has tornadoes in the form of whirl winds that whip up debris on the surface of Mars. These whirlwinds can be up to half a mile tall, although still relatively wispy, so they can exist but not as dramatic as the novel portrays.

Another scientific fact that Weir accurately presents is the communication system between Mark Watney up there on Mars and NASA on Earth. When the communication system at Watney's habitat is destroyed in the (questionable) storm, Mark finds no way but to communicate with Earth via the lander and the rover that touched down on Mars in 1997. Despite the fact that both of them needed a lot of work and maintenance before any of them could actually work; yet Watney already knew that. Theoretically it would be absolutely possible. Since Watney has already worked on the Pathfinder mission before, he knows that the spacecraft has been sitting up there since 1997 and it has certainly stopped operating because the batteries drained and gave out. So simply all what he has to do is to replace them and repower it and everything else will be functioninga again.

Overall, one can reach the conclusion that Andy Weir has did a lot of research for the sake of scientific accuracy of the ideas and the information he presents in The Martian without forgetting the fictional side that separates it from a pure extended scientific lecture in the form of a book. However, why would Weir choose the idea of travelling to Mars to be the dominant theme of The Martian? In a detailed interview with Zack Weissmueller, Andy Weir clearly replies, "I want us to have a self-sufficient population somewhere other than Earth" (38). This idea is rooted in Weir's mind because as a computer programmer he learnt the importance and the value of backing things up that is next to being a big fan himself of science and space travel, he

\section{ELLS Vol.8 No.I (61) December 2017}


believes in the role of science in providing the humans with all what it needs to explore and to survive on new planets.

Overviewing the already explained features of science fiction works, readers get the idea that The Martian is a clear embodiment of science fiction where Weir focuses on the accuracy of the information and the calculations presented to his redears. However, Weir's distinctive approach to science fiction is not merely falvoured by his own way of mixing advanced, accurate and complex scientific facts with interesting fictious elements as already explained. Moreover, Weir's science fiction is also known for redefining the classical boundaries of science fiction genre. The Marian combines many literary genres next to being a science fiction work. First of these is Robinsonades. A brief look at the Robinsonade's tradition and its variations seems like the normal place to start such a discussion.

Within a decade or two of the initial publication of Robinson Crusoe, its name has been lent to an emerging genre of stories involving being stranded after a shipwreck or any other adventure and the survival of an individual or small groups in remote derelict locales. Its name (Robinsonade) is coined by the German author Johann Gottfried Svhnabel in the preface of his own Robinsonade, Die Insel Felsenburg (Felsenburg Island 1731).

This literary genre is usually associated with tales of adventure and exploration. Robinsonades are not just stories of discovering strange and exotic places, but rather about creativity of making these places home for their adventuring protagonists. It goes without saying that the masterpieces that sets the standard for the genre is Daniel Defoe's Robinson Crusoe (1719). Throughout this novel, many critics set down the defining criteria of this genre. Consolmagno, Downing and other critics have mentioned the

ELLS Vol.8 No.I

(62)
December 2017 


\section{Dr. Ahmed Abdelsattar Abdelaziz Keshk}

following criteria for any literary work to be classified as a Robinsonade. In turn, the researcher will apply these criteria on The Martian to see how far a Robinsonade is The Martian as well.

First, the consciousness of a immeasurable world with important land areas still to be discovered, attracting people to the adventure of discovering it in spite of the imminent dangers of shipwreck and the high unlikelihood of rescue in that case. Applying this criteria on The Martian, Weir chooses a planet to be discovered not just an unknown land area. As the story goes, readers know that the first human team to touch the land of Mars is Watney's team. Moreover, readers appreciate and admire Watney's efforts and tries to survive alone on the Red Planet; yet they deeply get ready to hear the bad news that Watney can never be rescued. When all the odds are against him, NASA and readers alike, Weir allows Watney to express his feelings of being unlikely rescued. "Seriously this is it! I've had it! I have got a few minutes before I run out of air... All I have to do is to sit here. The air will leak out and I'll die" (158)

Second, the idea of the untold wealth of derelict place that enables a lonely shipwrecked man to build up his own life of solitude. It is worth noting that the second criteria is applied on The Martian in two different ways. The classical way of a Robinsonade in which Watney uses all the gears and tools provided by NASA not only for him but also for his friends. He also makes use of all the possibly useful items sent in previous missions, or even the existing requirements of the coming mission. However, the real wealth that saves Watney when even his dedicated fans give up is his resourceful scientific thinking. Both of the natural wealth of Mars as the Robinsonades highlights and the stateof-the-art technology would have never saved Watney's life. The novel presents another wealth to the Robinsonades, 
namely, scientific thinking. Without Watney's scientific approach of tackling crucial problems like providing food and water or relatively trivial problems like entertaining, he would have never lasted for a day up there. Planting his food, extracting water and building an efficient communication system with NASA from almost nothing are successfully achieved by applying existing scientific methods and theories.

Finally, the promise that man could be both adventurer and settler, both wild and domesticated is the third criteria of the Robinsonades. Actually, this is the most applicable criteria of Robinsonades on The Martian. Watney, regardless of all the challenges he faces, succeeds in building up a new life on Mars. Even if he was not going to be rescued until the coming mission to Mars - Ares 4 that is after 1387 sols - Watney would have certainly figured a way to settle down. Readers never doubted Watney for being a wild adventurer. He modifies the rover, faces a terrible dust storm, survives a rover roll over on the descent into Schiaparelli and even succeeds in modifying the complex MAV's weight all by himself in order to leave Mars safely. This adventurous side of Watney's character has never overcome his ability to create an environment to settle down. As a botanist and as an engineer, he succeeds to plant a crop of potatoes, fixing the canvas of the habitat and even finding the time to listen to disco music and to watch some recorded episodes of Three's Company. Watney proves to be an excellent settler and a bold sourceful adventurer as well.

Next to being a science fiction work vividly colored with the traditions of the Robinsonades, The Martian is flavored also with another literary genre, namely detective fiction. The Martian is an intellectually oriented work that proposes different intellectual problems that the reader is 
intended to solve. It is actually an exercise for the imagination. Among other features of The Martian, this point differentiates it from the long tradition of science fiction works. Gary Westfahl highlights this point by saying, "science fiction is similarly intellectually aimed; often it is just as much a riddle or puzzle tale... in modern science fiction, the science is almost always imaginative, and surprise endings are common" (202). Unlike other science fiction works, Weir presents The Martian in a way that depends on reliable existing scientific theories with an expected ending due to the understanding of the different clues.

Throughout 687 sols, Mark Watney must follow clues to discover new untraditional ways to survive and to control the cruel nature of Mars. If Watney fails at any moment to solve the mystery of that planet and if he does not reach an applicable solution for any problem he faces at any time, simply the cost will be his life without any given second chances. This gets clearer as the story develops, for example to solve the mystery and the puzzle of surviving in his journey to the MAV site, Watney shares with readers clues for that. He notes that:

I have to face facts. I'm done prepping the rover...Food: 1692 potatoes. Vitamin pills. Water: 620 Liters. Shelter: Rover, trailer, bedroom. Air: Rover and trailer combined storage... Life support: Oxygenator and atmospheric regulator. Power: 36 Kilowatt-hours of storage. Heat: 1400- watt RTG. Homemade reservoir to heat regulator's return air. Disco: lifetime supply. I'm leaving here on Sol 449. 
That gives me fifty-nine sols to test everything and fix whatever isn't working right...Since sol 6 all I've wanted to do was get the hell out of here. (268)

Andy Weir's The Martian is a science fiction work where the classical boundaries of the genre is blurred to add many features of the Robinsonades and detective stories to create a new literary matrix that avoids the traditional criticism directed towards science fiction works. Even the presentation of science in The Martian differs from the long traditional heritage of science fiction. Writers of science fiction works used to focus mainly on the literary sides of the novel and pay less attention to the scientific ideas since it is a literary work after all. In a sense, critics of science fiction works tend to "deemphasize science while emphasizing literary values" (207) as Westfahl simply summarizes it. As a result of that, science fiction works were studied and analyzed by ordinary critical standards with some attentiveness to scientific accuracy. An emphasis on the latter factor is not usually placed to be replaced with a focus on the fiction with all its social, moral and philosophical ideas.

Andy Weir did not only present to his readers well researched scientific ideas as proved previously, but he also succeeded in depicting scientists' life and other culture. The Martian does capture the culture of science - the way scientists talk, the way they interact, their motivations and their response to extreme failure. Unlike the classical image of scientists in science fiction works as calculating, antisocial, almost never confident and rarely funny humans like robots, Mark Watney is the antidote to that trope. He is 


\section{Dr. Ahmed Abdelsattar Abdelaziz Keshk}

funny, and may be his humor helped in saving him from losing his mind up on Mars. Watney is not alone, many engineers and scientists in the book match him in wits and humor. The other scientists and engineers in the book also run counter to the traditional image of scientists' stereotype. Commander Lewis, for example, is a Navy-trained geologist leading a major human mission to Mars who also loves disco music and TV shows from the 1970s. In an interview with Steve Spaleta, Weir highlighted the idea that, "It wasn't just about the technical side being right. I do not want to say it is the easy part, but we can look that stuff up. The tricky part is getting the way scientists talk".

Even the theme of The Martian has broken the stereotypical image of space stories. Traditional plots of space adventures revolve around something terrible happening in space. An asteroid is headed towards Earth, the core of the Earth stops spinning, the sun starts radiating too many particles, or even deadly space debris being directed to Earth. The Martian begins with an extraordinary circumstance: An astronaut is mistaken for dead, and is left alone and injured on Mars with no communication with Earth. But beyond all that, all the obstacles that Watney challenges are normal. In other words, it is a survival story in space that does not need asteroids or space debris to pay its readers' attention or to prove that it belongs to the genre of science fiction. By using real obstacles as Watney's enemy, Weir succeeded in both relating to normal readers who are not interested in advanced technology stories and using existing scientific and technological forms and theories.

Finally, with so many space books centered on a terrible space catastrophe, it is no wonder that normal readers of such stories end up believing that space is the enemy. These books have created a feeling that space itself is a kind of monster that inspires nothing but fear. This fear, 
or even hatred, of space might be the single biggest inaccuracy in most space related science fiction works. The history of space travelling does contain fatalities, some of which arose out of horrible, preventable circumstances. While these events initiate action, reflection, and mourning; they have never made people stop wanting to explore space. The Martian highlights this idea very well. Even when NASA thinks that Watney is dead, people still keep thinking and planning the next human trip to Mars. The Martian shows that despite every effort to keep astronauts alive, space flight and space exploration carry with them the possible risk of death, and astronauts willingly accept that. Even when Watney finds himself at one of his lowest points, when he is drafting a letter to his parents knowing that they may very well outlive him, he tells them. "I love what I do" (The Martian,2). Actually, Mark reflects Weir's belief in the necessity of finding a planet to live on next to Earth. Weir clearly says that:

As long as our entire species is on one planet, we risk extinction. It's not very likely, but it could happen. It could be a war. It could be a meteor strike or something like that. But if we're on two planets, it is practically impossible for us to die. And part of colonization is figuring out how to send humans to Mars.

(Weissmueller,43)

In other words, The Martian is not only about the survival story of Mark Watney, but it also explores further the importance to seek, to strive, to find and not to yield. 


\section{Dr. Ahmed Abdelsattar Abdelaziz Keshk}

Through accurate application of existing scientific knowledge, Weir manages to maintain a clear level of believability equal to the fast pace of the narrative. From the very first page to the last, The Martian attracts the reader not to put it aside or to pause reading. Just one more log, The Martian whispers, "what will happen next to Watney?" Like any thriller, The Martian depends on providing so many poor odds of survival. Like any good thriller, The Martian navigates Watney out of these situations by innovative believable means, and like any excellent science fiction work, every page is filled with the promise of Watney's death, or a clever solution to a hopeless situation. Some of the tension is softened by the narrative structure of The Martian since it is mainly written in the form of Watney's hand typed mission logs. Through these logs, Watney succeeds in recording his attempts at survival in the hopes that a future Mars mission will recover them to reach new scientific explanations of how to live, plant, and to survive Mars.

One issue with this approach is that the logs have difficulty establishing any emotional connection with the reader. Indeed, they are interesting and scientific but due to their very nature, the logs are just a recorded history, rather than a human dialogue between the reader and the narrator. As a result, the novel lacks the intense emotional bond that readers often form with first-person narrators. Add to that, the enormous amount of technical and scientific discussions in the book may read like a Wikipedia article to the reader. Andy Weir avoided this by adding a sense of humor to space exploration. Every few paragraphs, there is something that makes readers smile and even laugh, and that is really important to keep readers interested through all this exposition.

\section{ELLS Vol.8 No.I (69) December 2017}


Using humor is not the only narrative technique that Weir adopted to attract readers to follow Watney's survival story. Weir also deliberately uses common simple jargons to express his own feelings in the logs. Readers identify with Watney in expressing his own feelings of happiness, success, anger and disappointment. Even Watney curses and calls things names when he is very depressed unlike the common image of scientists being so preserved. The book opens with Watney's witty voice "I'm pretty much f--ked" (1) to describe his miserable hopeless case of being left badly injured alone on Mars.

Weir also cleverly helps readers to identify with the characters of The Martian not only by using simple language to deal with advanced scientific problems, but he also avoids to physically describe any male or female characters even Mark himself. Avoiding physically describing the characters, readers pay attention only to their plans and opinions to save Watney. Being tall or short, fat or thin, white or black has nothing to do with being smart or not. The image of Watney and all the other characters helping him on Earth are never described physically. Readers can only describe them and identify with them after reading the novel by their suggestions and efforts to save Watney. They are normal typical humans like any reader of The Martian.

Andy Weir throughout The Martian does not attend to deal with science in a fictionalized form like many other science fiction writers; on the contrary, he uses science, and moves into unlimited fictionalized world where readers can share with the characters all their moments of success and failure alike. Andy Weir clearly succeeds in knowing where his science ends and his fiction begins. Weir and his hero Mark Watney manage to combine wit with emotional depth that fascinates the hearts and the minds of both readers and 
Dr. Ahmed Abdelsattar Abdelaziz Keshk

listeners through shifting perspectives, from the lone American on Mars, to crew members travelling towards Earth, to the NASA team desperate to save the castaway. This helps Weir to investigate a specific aspect of life which no other science fiction work did reflect before, namely the relation of man to science in which man always controls, reshapes and directs science not the other way around. This relation opens the door for the rebirth of a new science fiction trend where the human mind masters science as well as all the related forms of technology. This trend of science fiction combines between many other genres in one single literary matrix that is known for its simple language and innovative ideas.

ELLS Vol.8 No.I (71) December 2017 


\section{REFERENCES}

\section{PRIMARY SOURCES.}

- Weir, Andy. The Martian. New York: Random House Group Company, Inc. 2014.

\section{SECONDARY SOURCES}

- A.B.E. "A" Stepping Stone" Study of Early Science Fiction". Science Fiction Studies. Vol. 21, No.3 (November, 1994), pp.418420.

- Angenot, Marc. "Three Special Issues on Utopian Fiction". Science Fiction Studies. Vol.3, No.3 (November, 1976), pp.313315.

- Anon. "A History of Science Fiction Criticism: Collective Works Cited and Chronological Bibliography". Science Fiction Studies. Vol. 26, No. 2 (July, 1999), pp. 263 - 283.

- Anon. "A Martian Model". Time. Vol.95, No.3 (1970), p.46.

- Anon. "I have no idea what I did Right". The Chemical Engineer. (November, 2015),pp. 36-38.

- Anon. "Volume Information". Science Fiction Studies. Vol.11, No.3 (November, 1984), pp.347- 350.

- Anon., "Volume Information". Science Fiction Studies. Vol.3, No.3 (November, 1976), pp. 316-319.

- Anon., "Volume Information". Science Fiction Studies. Vol.18, No.3 (November, 1991), pp. 460-463.

- Attebery, Brian. "Review Essay: Beautiful Genre". Journal of the Fantastic in the Arts. Vol.21, No.1 (2010), pp.97-104.

- Benford, Gregory. "Science Fiction Faces Facts". Reason. Vol. 43, No.9 (October 2016), pp1-4.

- Bereit, Virginia F. "The Genre of Science Fiction". Elementary English. Vol.46, No.7 (November, 1969), pp. 895-900.

- Bryant, Jeff. "Navigating Mars in The Martian". Planetarian. Vol.16, No.5 (December, 2015), pp.22-23.

- Burkey, Mary. "The Strange Journey of The Martian: An Indie Success Story". Spotlight on First Novels. (November,2015), p.16. 
- Chown, Marcus. "Is Science Fiction Dying?". New Scientist. Vol. 199, No. 2682, (November 2008) pp. 46 - 49.

- Colatrella, Carol. " Science Fiction in the Information Age". American Literary History. Vol. 11, No. 3 (Autumn, 1990). Pp. 554- 565.

- Consolmagno, Guy J. "Science Fiction and Popular Culture: 1277 to 2001 And Beyond". Leonardo. Vol. 29, No. 2 (1996) pp. $127-132$.

- Daniel, Tony. "Lonely Red Planet". Publishers Weekly. (November, 2015). P.49

- Davis, Kristin. "10 Questions for Andy Weir". Aerospace America. Vol.54, Issue.3, (March, 2016), pp.16-17.

- Derleth, August. "Contemporary Science Fiction". The English Journal. Vol. 41, No. 1 (January 1952) pp. 1 - 8.

- Downing, Karen. Restless Men: Masculinity and Robinson Crusoe. England: Palgrave Macmillan UK, 2014.

- Driscoll, Molly. "Oscar 2016: Why has no sci-fi movie ever won Best Picture?". Christian Science Monitor (February, 2016), N. PAG.

- Feeley, Jennifer L. and Sarah Ann Wells (Editors). Simultaneous Worlds: Global Science Fiction Cinema. Minneapolis: University of Minnesota Press, 2015.

- Ferreira, Rachel Haywood. "Back to the Future: The Expanding Field of Latin-American Science Fiction". Hispania, Vol. 91, No. 2 (May 2008), pp.352-362.

- Freedman, Carl. Critical Theory and Science Fiction. Middletown: Wesleyan University Press, 2013.

- Frelik, Pawl. "The Many Tongues of Science Fiction". Science Fiction Studies. Vol.30, No.1 (March,2003) pp.144-146.

- Gold, John R. "Darkened Skies: The City in Science Fiction Film". Geography. Vol. 56, No. 4(October 2001) pp.337- 345.

- Gunn, Eileen. "Brave New Words". Smithsonian. Vol.45, Issue 2 (May, 2014), pp. 43-37.

- Herotic, Steven. "The Evolution and Extinction of Science Fiction". Public Understanding of Science. Vol.23, No. 8, (November, 2014), pp.996-1012.

\section{$\begin{array}{lllll}\text { ELLS Vol.8 No.I (73) December } 2017 & \end{array}$}


"Just because I can"

To the Mars and Back: A Study of the Rebirth of Science Fiction in Andy Weir's The Martian

- Hutchins, Henry Clinton. "Some Limitations of Robinson Crusoe called Robinsonades". The Yale University Library Gazette. Vol.11, No.2 (October 1936) pp. 32-36.

- Joe, Ryan. "The Martian Chronicle". Audio. (2015), pp.22 - 23.

- Kafka, Janet. "Why Science Fiction?" The English Journal. Vol. 64, No. 5(May, 1975), pp.46-53.

- Kanas, Nick. "Psychology in Deep Space". The Psychologist. Vol.28, No. 10 (October 2015), pp. 804-807.

- Kandel, Michael. "Is Something New Happening in Science Fiction?". Science Fiction Studies, Vol. 25, No. 1 (March 1998), pp. 1-6.

- Ketterer, David, Eric S. Rabkin and Raffaella Baccolini. "Science Fiction and Imagination". PMLA. Vol. 120, No. 1 (January 2005), pp.426 - 429.

- Landon, Brooks. "Review: Reading the Red Planet". Science Fiction Studies. Vol. 39, No. 2 (July 2012), pp. 313 - 326.

- Larson, David M. "Science Fiction, The Novel, and the Continuity of Communication". The Journal of General Education. Vol. 28, No. 1 (Spring 1976), pp. 63-74.

- Latham, Rob. "Who Killed Science Fiction". Science Fiction Studies. Vol.34, No.1 (March, 2007). pp. 171-173.

- Lodge, Guy. "The Martian". Final Cut. (2016), pp 134-135.

- Lunau, Kate. "The Martian". Maclean's. Vol.127, Issue. 9 (October, 2014), pp.59-60.

- Maxwell, Ann. "Becoming Martianized: Liberal Eugenics and H. G. Wells" Star Begotten". English Studies. Vol. 93, No. 6 (October, 2012), pp. 683 - 699.

- Moore, Bryan L. "Evidences of Decadent Humanity". Nature and Culture. Vol.9, No.1 (Spring 2014) pp. 45 - 65.

- Moskowitz, Sam. "The Early Coinage of Science Fiction". Science Fiction Studies. Vol.3, No.3 (November 1976) pp. 312313.

- Norton, Eric. "Q \& A: Andy Weir". Library Journal. Vol.138, No.21 (2013) p.78.

- Oberhelman, David D. Historical Dictionary of Science Fiction Literature. Lanham, MD: Scarecrow Press, 2005. 


\section{Dr. Ahmed Abdelsattar Abdelaziz Keshk}

- O'Malley, Andrew. Children's Literature, Popular Culture and Robinson Crusoe. London: Palgrave Macmillan, 2012.

- Oravetz, David. "Science and Science Fiction". Science Scope. Vol.28, No.6 (March 2005),pp. 20-22.

- Ott, Bill. "Letter from the Editor". Booklist.Vol.112, Issue 4, (October, 2015), p.118.

- Panshin, Alexei. " Science Fiction Bibliography and Criticism". American Libraries. Vol. 1, No. 9 (October, 1970), pp. 884 - 885.

- Pohl, Fredrik. "The Study of Science Fiction: A Modest Proposal". Science Fiction Studies. Vol. 24, No.1 (March, 1997). Pp. 11-16.

- Quante, Michael. "Being Identical by Being Treated as Responsible". Autonomy and the Self. Vol. 118, (October 2012), pp. 253 - 271.

- Rabkin, Eric S. "Fiction and the Future of Criticism". PMLA. Vol. 119, No. 3 (May, 2004), pp. 427- 473.

- Rainer, Peter. "The Martian is entertaining but lacks awe". Christian Science Monitor. (October,2015), pp.4-7.

- Rea, Jennifer A. "From Plato to Philip K. Dick: Teaching Classics Through Science Fiction". The Classical Journal. Vol. 105, No. 3 (February- March 2010), pp. 265-275.

- Rieder, John. "Life Writing and Science Fiction: Constructing Identities and Constructing Genres". Biography. Vol.30, No.1, (Winter 2007) pp. V-XVII.

- Riggspy, Dutchie S. "Would you believe? Science Fiction". Science and Children.Vol. 6, No. 3 (November 1968), pp. 21-22.

- Roberts, Adam. The History of Science Fiction. Hampshire: Palgrave Macmillan, 2006.

- Rottensteiner, Franz. "Recent Books on Science Fiction from Germany". Science Fiction Studies. Vol. 12, No. 2 (July 1985) pp. $209-220$.

- Russ, Joanne. "Towards an Aesthetic of Science Fiction". Science Fiction Studies. Vol.2, No. 2 (July, 1975), pp. 112-119.

- Russel, W. M. S. "Folktales and Science Fiction". Folklore. Vol. 93, No. 1 (1982), pp. 3 -30. 
"Just because I can"

To the Mars and Back: A Study of the Rebirth of Science Fiction in Andy Weir's The Martian

- Samuelson, David N. "On Hard Science Fiction: A Bibliography". Science Fiction Studies. Vol. 20, No. 2 (July, 1993), pp. 149-156.

-"Science Fiction". Encyclopedia Britannica, Inc., 3 May. 2016. https://08107gho.1104.y.http.academic.eb.com.mp16.ekb.eg/level s/collegiate/article/66289. Accessed 21 July 2016.

- Scolte, J. H. "Robinsonades". Neophilologus. Vol.35, Issue. 1, (December 1951), pp.129-138.

- Sebesta, Judith. "What I'm Reading: The Martian". Chronicle of Higher Education. Vol.62, Issue 12, (November, 2015), p.17.

- Seedhouse, Erik. Survival and Sacrifice in Mars Exploration. Switzerland: Springer International Publishing, 2015.

- Semley, John. "Lost in Space, Without the Angst". Maclean's Magazine. (October, 2015). pp.58-60.

- Simak, Clifford D. "SF/Fantasy/Horror Notes". Publishers Weekly.Vol.251, No.44 (2004) pp.48-49.

- Spaleta, Steve. "How to Kill or Save A Martian? Author Andy Weir Knows". An Interview. Space.com. (August 25). 2015. 2:52 pm. https://www.space.com/30365-how-to-kill-or-save-a-martianauthor-andy-weir-knows-video.html.

- "The Martian". Wikipedia, The Free Encyclopedia. Eric White. American University in Cairo. (Retrieved) 2 July 2016. https://en.wikipedia.org/wiki/the_martian_weir_novel.

- Tymn, Marchall B. "A Brief History and Review of Criticism". American Studies International. Vol. 23, No.1 (April 1985), pp.41-66.

- V. H. "A Commonwealth of Science Fiction". Science Fiction Studies. Vol. 31, No. 3 (November, 2015). P. 500.

- Vilkomerson, Sara and Tamer Hanuka. "The Man Who Rediscovered Mars". Entertainment Weekly. (July,2014), pp.3235.

Weir, Andy."Interview". Smithsonian. Vol.46, Issue 5, (September 2015), p.12

- Weissmueller, Zack. "The Man Behind The Martian". Reason. Vol. 47, Issue 8, (January 2016), pp.38-43. 


\section{Dr. Ahmed Abdelsattar Abdelaziz Keshk}

- West, Robert H. "Science Fiction and its Idea". The Georgia Review. Vol.15, No.3 (Fall 1961) pp. 276 - 286.

- Westfahl, Gary. "A Symbol for Science Fiction". Science Fiction Studies, Vol. 22, No.1 (March 1995), pp. 1- 21.

- Westfahl, Gary. "The Popular Tradition of Science Fiction Criticism". Science Fiction Studies. Vol. 26, No. 2 (July, 1999), pp. 187-212.

- Westfahl, Gary. "The Popular Tradition of Science Fiction Criticism". Science Fiction Studies. Vol.26, No.2 (July 1999), pp.187-212.

- Williams, Raymond. "Science Fiction". Science Fiction Studies. Vol.15, No.3, (November, 1988), pp.356-360.

- Wilton, Shirley M. "Juvenile Science Fiction Involves Reluctant Readers". Journal of Reading. Vol.24, No.7 (April, 1981), pp. 608- 611 . 
"Just because I can"

To the Mars and Back: A Study of the Rebirth of Science Fiction in Andy Weir's The Martian 